\title{
Coastal community livelihood dependency on Mahanadi Mangrove Delta, Odisha.
}

\author{
Subhechha Tapaswini*, Sabmeet Singh ${ }^{* *}$, NPS Chauhan* \\ * Forestry and Wildlife sciences, Amity institute of Forestry and Wildlife sciences \\ ${ }^{* * *}$ Department of Wildlife sciences, University of Kota \\ DOI: 10.29322/IJSRP.10.06.2020.p10290 \\ http://dx.doi.org/10.29322/IJSRP.10.06.2020.p10290
}

\begin{abstract}
Natural ecosystems such as corals, mangroves are fundamental life support system without which human civilization cannot exist. Ecosystem has 3 major functions such as, Bio geographical, Ecological, and Anthropogenic. Mangroves are global ecosystems of which function includes storage of water, biological productivity, biogeochemical transformation, habitat for flora and fauna. The mangrove ecosystem provides goods and services to the local community and other communities all over the world. It also includes shoreline protection from storm and flood. These functions are called as indirect use value according to economist. Ecosystems are natural capital stock which can provide goods, provide erosion control, and recreational activities. In this study four objectives are taken into consideration. For this, questionnaire survey was conducted and 170 households were chosen from six villages. Dependency of community on mangrove delta is observed in two scales i.e. Occupation status of local community and fuel use pattern respectively. In this study human wildlife conflict and attitude of local community towards the conservation of mangrove was also observed. Techniques and simple statistics were used to analyze the data to derive a logical conclusion. This study reveals that fisheries is the major occupation and source of income for local people and for fuel most people are dependent on cow dung, coconut leaves and firewood collected from forest. This study shows a preliminary baseline data about local people dependency on mangrove forest and implies that community involvement should be carried out to achieve a sustainable mangrove conservation goal.
\end{abstract}

Index Terms- Mahanadi mangrove delta, Livelihood, Human wildlife conflict, Conservation

\section{INTRODUCTION}

Mangroves are coastal vegetation found in river delta and coastline of India (Day et al., 1987). Their growth can only be possible in the intertidal zones with salinities. They are the habitats for many marine flora and fauna that grow well in the estuarine areas (Selvam et al.,2010). The leaves of the mangrove trees are highly nutrient rich. It is a detritus based ecosystem so it is highly productive and maintains both terrestrial and aquatic environment. Mangrove wetland has many uses that performs number of ecological and economical functions to sustain biodiversity and gives livelihood security to coastal communities (Kathiresan and Bingham, 2001). Mangrove ecosystem act as natural barrier against cyclonic storms, are habitat for sport and commercial fisheries. It prevents soil erosion, facilitates nutrient such as nitrogen and sulfur cycling (Alongi 1994; Holguin et al. 2001; Rojas et al. 2001). It is also a global carbon sink. It is the adobe for many birds, estuarine crocodile and various other fauna (Ong, 1995) due to high leaf production, leaf fall and rapid breakdown of the detritus (Aksornkoae, 1986). The economic value of mangrove wetland is they provide timber, poles, posts and firewood, they provides non timber forest products such as fodder, honey, thatching material etc.

\footnotetext{
Mangroves of Odisha

Orissa is located between $17^{\circ} 49^{\prime} \mathrm{N}$ and $22^{\circ} 34^{\prime} \mathrm{N}$ latitudes and between $81^{\circ} 27^{\prime} \mathrm{E}$ and $87^{\circ} 29^{\prime} \mathrm{E}$ longitudes. $52,472 \mathrm{sq} \cdot \mathrm{km}$ is forested area, which amounts to $33.7 \%$ of the geographical area. Out of 52,472 sq.km of forested area mangrove forests cover constitute 243 sq. $\mathrm{km}$. It is only about $0.46 \%$ of the total forest area of the Odisha. The Mahanadi, Brahmani and Baitarani rivers shows tremendous growth of mangrove forests, which are habitat of many organisms and shows high faunal diversity and biomass. Salt tolerant paddy and aquaculture is the major practice of costal belt people of Odisha in the mangrove areas. The mangrove all along Odisha coast are threatened due to booming population high demand of lands for agriculture and prawn farming. The patch of mangrove over Bhitarkanika is well preserved due to declaration of protected area but the mangrove vegetation in the Mahanadi delta region between Barunei mouths to Mahanadi mouth (Paradwip) is fragmented and degraded due to large scale encroachment. Large mangrove forest areas have been converted into artificial fishing pond and agriculture land for these purposes. In Paradwip area, large tracts mangroves were cleared for the development of Paradwip port and pesticide industry.
} 
There is high dependency of local people in mangrove all over India. In Odisha local people are dependent on mangroves to meet their daily needs. In Bhitarkanika most of the people are dependent on mangroves for their basic livelihood so as in Mahanadi delta. There is very scattered information about the people's dependency and conservation threats to mangrove forest of Mahanadi delta. This study is the first to enlighten up the livelihood, resource dependency of fishing community and threats to mangrove forest of Mahanadi delta. This is the first baseline study which was conducted in this area provides better understanding and the extent of people's occupation and dependency over Mangrove forest on Mahanadi Delta.

\section{METHODOLOGY}

Objectives of the study

- Dependency of local community on different occupation

- $\quad$ Fuel items used by local community

- Human Wildlife Conflict

- Conservation Attitude

This study was based on three aspects - First aspect was study of socioeconomic status, land use, different resource use, and occupation of randomly selected households in 6 villages in the Batighara panchayat nearby Mahanadi mangrove, second aspect was assessing the attitude of local people towards conservation of mangrove and third aspect was a qualitative survey on human wildlife conflict.

Accordingly the following different methodologies were adapted which are described below

\section{SOCIO-ECONOMIC CHARACTERSTICS OF VILLAGES, LEVEL OF DEPENDENCY ON THE FOREST FOR DIFFERENT RESOURCES.}

A questioner was well designed to meet the objectives properly. It was mainly comprised of various qualitative questions for getting data about the consumption and collection of fuel wood, fodder, nontimber forest product. In this type of survey, close ended semistructured questioners has been used, households are taken as units to access the resource use dependency and how they sustain their livelihoods, their attitudes towards conservation has also been accessed. By using questionnaire survey socioeconomic parameter like household size, occupation, harvesting and use of forest resources were collected.

\section{SOCIOECONOMIC ASSESSMENT}

The household were chosen randomly without any biases. Households are selected from different groups; high, middle and low. Only one adult member from the household was selected for interview basically the interviewee was the head of the family and experienced. A single questionnaire was used for the whole interview. First some basic information's such as gender, education level, age, length of residency), household characteristics (household size, land owned, source of household income), occupation, land-use, and resource use pattern was taken into consideration for this survey. An informal discussion was carried out. Each interview took thirty minutes. Each interviewee was cleared about this survey that it is conducted for academic purpose to avoid bias. Each households was questioned about their source of domestic energy to estimate their dependency on forest resources and their requirement of fuel wood. The data for substitute of fuel wood was also collected from this this survey.

\section{ATTITUDE OF LOCAL PEOPLE TOWARDS CONSERVATION OF MANGROVE AND HUMAN WILDLIFE CONFLICT}

For this survey a different close ended semi structured questioner survey was conducted. This was an informal discussion. People of age class 20 and above were selected for this survey. People were participated by their own interest. The interview was conducted in Odia language.

\section{Sampling:}

The sampling we used for this study is totally based on the objective. The first purposive sampling was used for selecting the study location such as selection of a district, selecting block, selecting panchayat and selecting village and the mangrove area for conducting the study. The base used for this sampling was coastal people who have been residing besides the mangrove forest for the last fifteen to twenty years. 


\section{RESULTS}

\section{Analysis of resource use pattern and livelihood of households of Village-1}

Two things basically firewood and fodder are highly collected material from forest in India. We observed that the fuel wood is consumed on a monthly basis. In all 170 household of the surveyed study panchayat most of the families collected fuel wood as a chief source of fuel .Other products are also used by families such as cow dung, woods and leaves from orchard, kerosene, LPG. Few villages in the surveyed panchayat is facilitated by LPG. All households are supplemented with Kerosene by Odisha government's Rashaan card. Out of 170 households of Batighara panchayat 18 households of a village named as Nipania income source depends on Fisheries. Some of them are Share cropper, Rice cultivator, Daily laborer .Some people have their shops, Boat business etc.

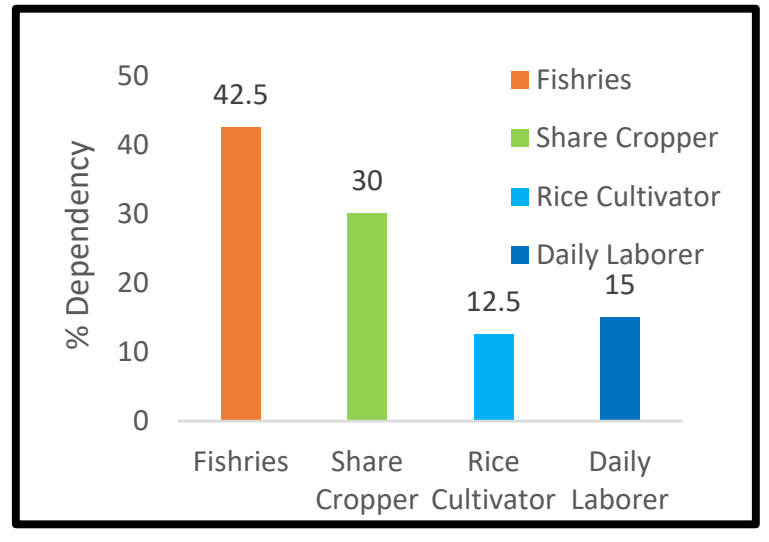

Figure 1: Percentage dependency of local community on differenoccupation

The graph 1: shows that in this village out of 18 observation 17 family $42.5 \%$ people are dependent on fisheries. Share croppers are also taken into consideration in this survey out 18 observation 12 people $30 \%$ people are share croppers i.e. they don't have their own farm land and they usually cultivate on other's farm. $12.5 \%$ people are rice cultivators. $15 \%$ people are daily laborers. The major source of occupation of this this village is Fisheries after that Share cropping then Daily laborer. Least people depends on rice cultivation.

\section{Fuel use}

There are different aspects for fuel of local people mostly for cooking purpose. This area is broadly divided into different categories such firewood consumption from forest, orchard wood, cow dung, LPG.

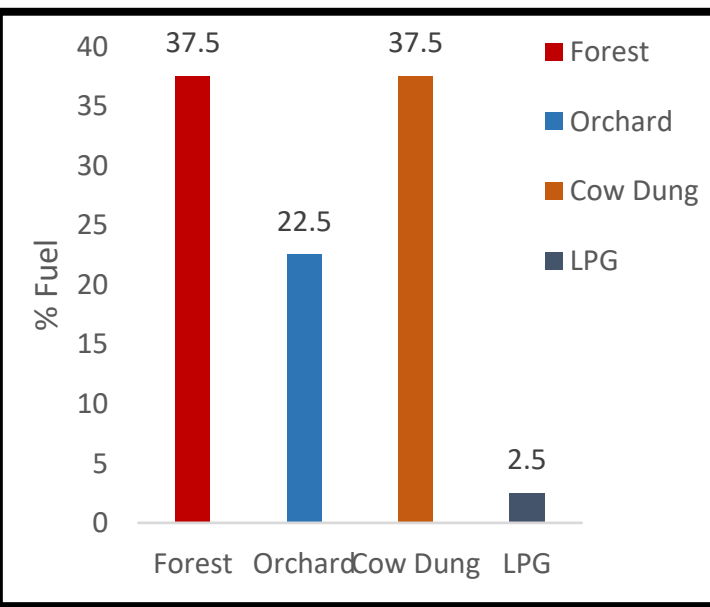

Figure 2: Percentage fuel items used by local Community

The graph 2: shows out of 18 observation responses are - 37.5\% people are dependent on forest for firewood, $22.4 \%$ people are dependent on orchard wood, and $37.5 \%$ people are dependent on cow dung only $2.5 \%$ people are dependent on LPG for cooking. Maximum people are dependent on forest and cow dung for cooking. After that people are consuming wood from their own orchard. The least amount of people are dependent on LPG. 


\section{Analysis of resource use pattern and livelihood of households of Village-2}

Out of 170 observations, 7 observations were taken from another village, namely, Batighara of the same panchayat covering the same aspects. First is the occupation dependency and the next is the firewood consumption.

The graph 3: shows out of seven observations $20 \%$ people are dependent on fisheries, $0 \%$ are share croppers, $30 \%$ are rice cultivators, and $50 \%$ are daily laborers. According to this graph more people are daily laborers followed by rice cultivators and fisheries.

\section{Fuel use}

The next aspect is fuel consumption by local community for daily cooking purpose. The figure 4 shows $18.7 \%$ people are dependent on firewood from forest, $37.5 \%$ people are dependent on orchard for wood collection, $37.5 \%$ are dependent on cow dung, and $6.25 \%$ people are dependent on LPG. Local people dependency is more on orchard wood and cow dung followed by forest and LPG.

\section{Analysis of resource use pattern and livelihood of households of Village-3}

The graph shows out of 170 households 44 observations shows the following trend of occupation i.e. $25.9 \%$ people are dependent on fisheries, $18.18 \%$ people are share croppers, $15 \%$ people are rice cultivators, $19.48 \%$ people have ether their own shops and $20.77 \%$ people are daily laborers. Highest income source of this village people depends on fisheries followed by daily laborers, alternative occupation such as (boat business, vegetable shops) share cropper and rice cultivation.

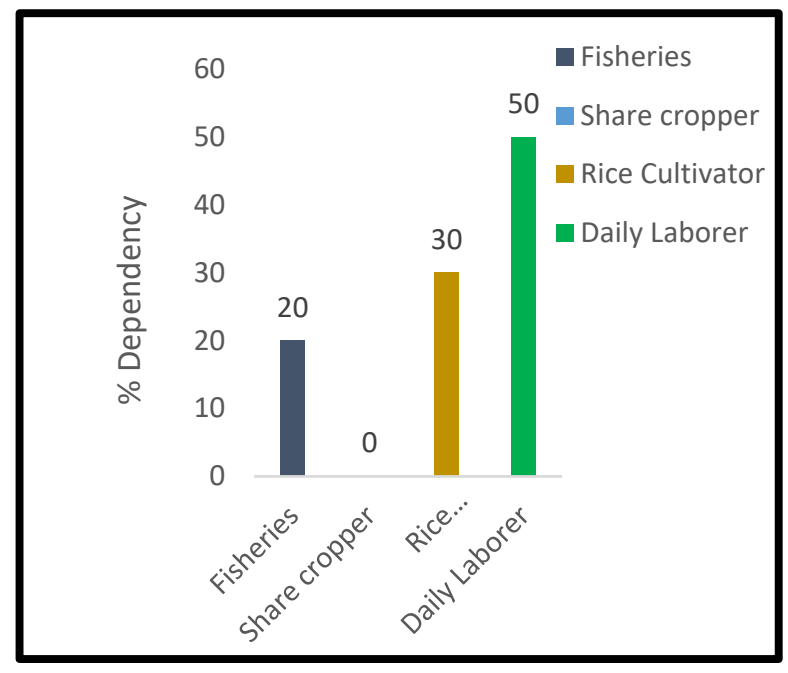

Figure 3: Percentage dependency of local community on different occupation

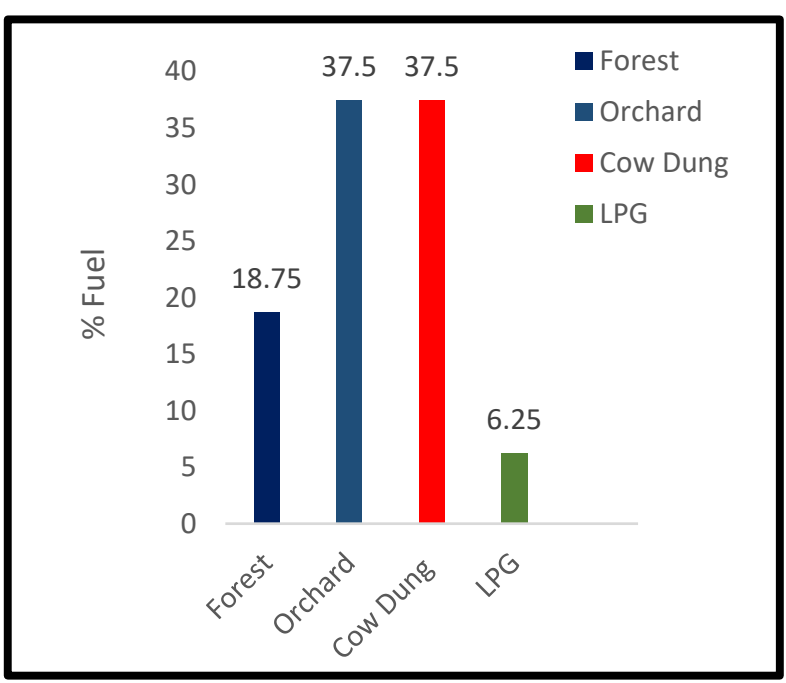

Figure 4: Percentage fuel items used by local community

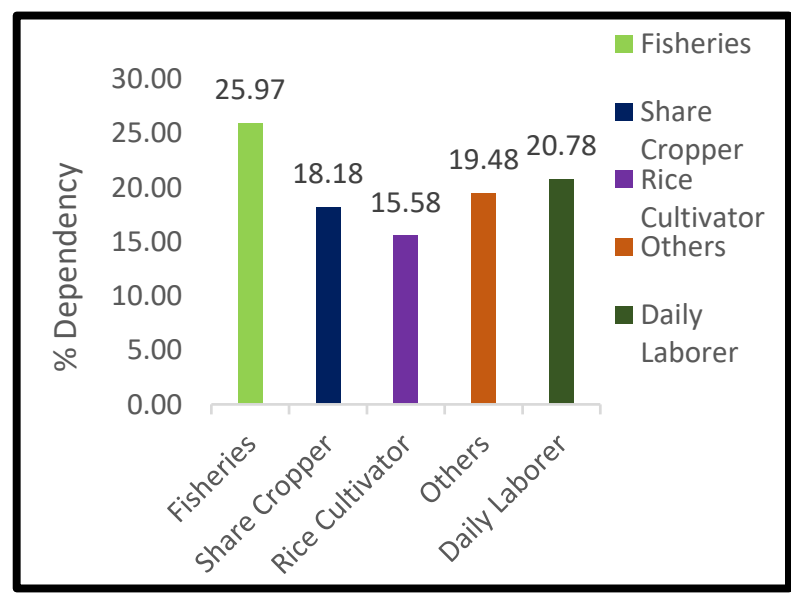

Figure 5: Percentage dependency of local community on different occupation 


\section{Fuel use}

The graph 6: shows responses of people towards different fuel item. Among 44 observations $27.7 \%$ people are dependent on forest for firewood consumption, $26.7 \%$ people are dependent on orchard wood, $34.6 \%$ people are dependent on cow dung and $10.8 \%$ people use LPG. Cow dung is used by maximum people. Firewood from forest is the third most consumed item by people after cow dung.

\section{Analysis of resource use pattern and livelihood of households of Village-4}

More 38 observations are taken in a village TUBI of the same panchayat. The above graph shows $54.3 \%$ people are dependent on Fisheries for their daily occupation, $44.3 \%$ people are share cropper $0 \%$ people are rice cultivator, $1.4 \%$ people are daily laborer, $0.0 \%$ people have other occupation. Major occupation of local people is fisheries followed by share cropping, daily wage laborers. There is no other occupation source and people don't have agricultural land so people are not able to cultivate rice for their own.

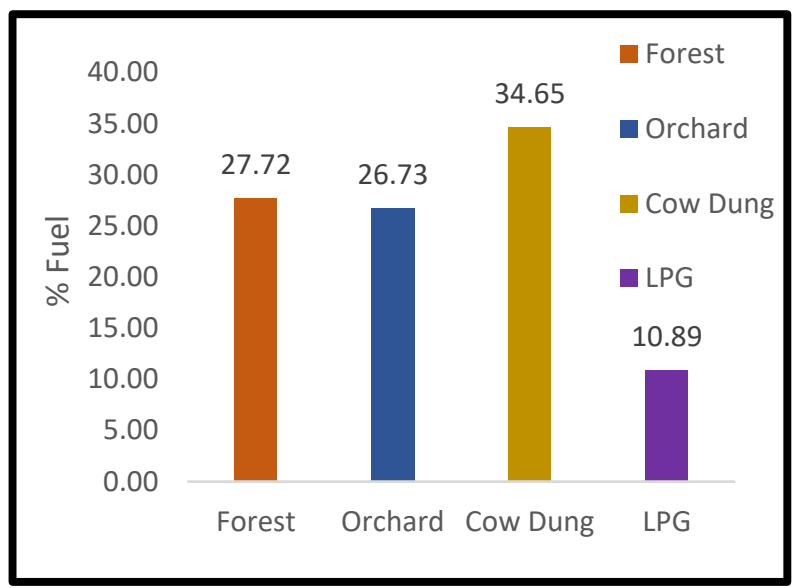

Figure 6: Percentage fuel items used by local community

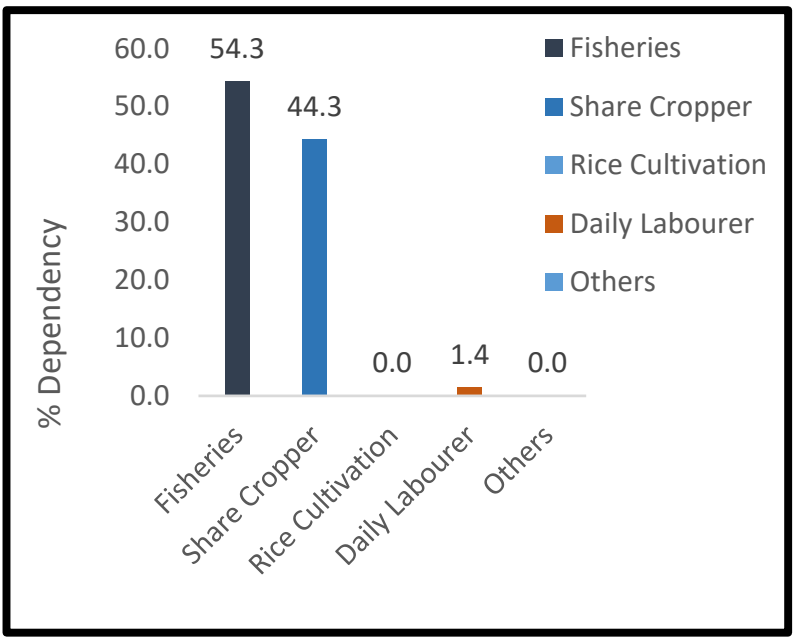

Figure 7: Percentage dependency of local community on different occupation

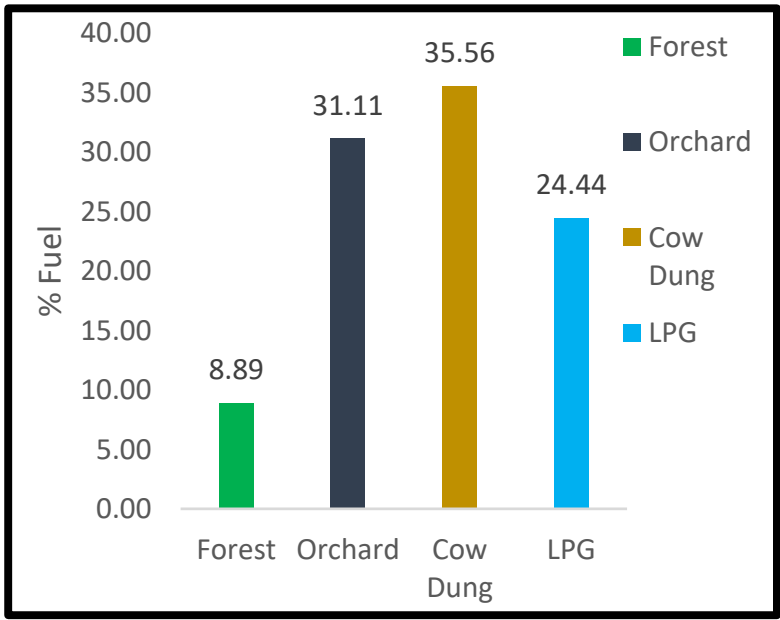

Figure 8: Percentage fuel items used by local community

\section{Fuel use}

The percentage of firewood collection from forest is $8.8 \%, 31.1 \%$ for orchards, $35.5 \%$ for cow dung, and $24.4 \%$ for LPG. This shows people of this village is highly dependent on cow dung followed by orchard wood, LPG and firewood from forest. 


\section{Analysis of resource use pattern and livelihood of households of Village-5}

Further 18 observation is carried out in another village named as kochila The graph 9: shows 41.37\% people are dependent on Fisheries, 10.344\% people are dependent on share cropping, 20.68\% people are dependent on rice cultivation, $3.44 \%$ people are dependent on other occupations, $24.13 \%$ people worked as daily laborer. Hence in this village maximum people are dependent on fisheries followed by daily laborer.

\section{Fuel use}

The graph 10: shows $21.6 \%$ people are dependent on Forest, $31.83 \%$ people are dependent on firewood collected from forest, $37.8 \%$ people are dependent on orchard wood, $37.83 \%$ people are dependent on Cow dung, $2.70 \%$ people are dependent on LPG. Here, Maximum used material is cow dung and orchard wood followed by second highest commodity i.e. fuel wood consumed from forest. LPG is used least by the people.

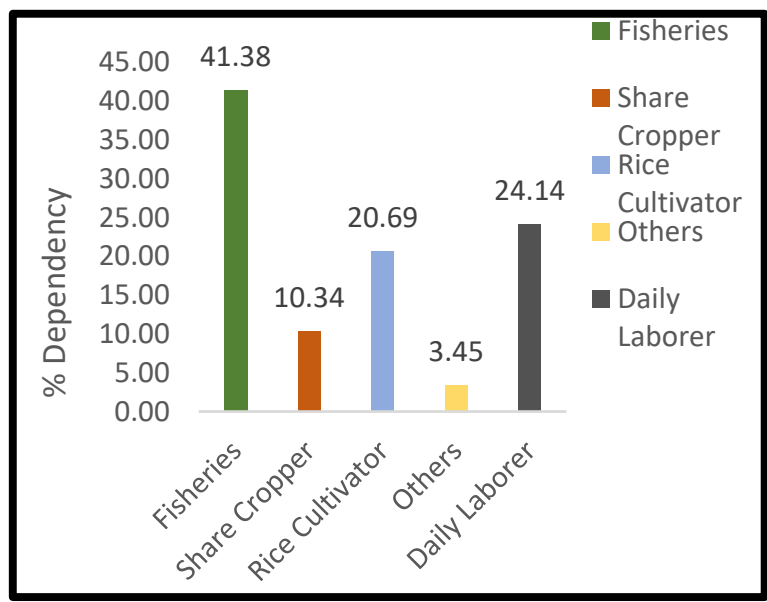

Figure 9: Percentage dependency of local community on different occupation

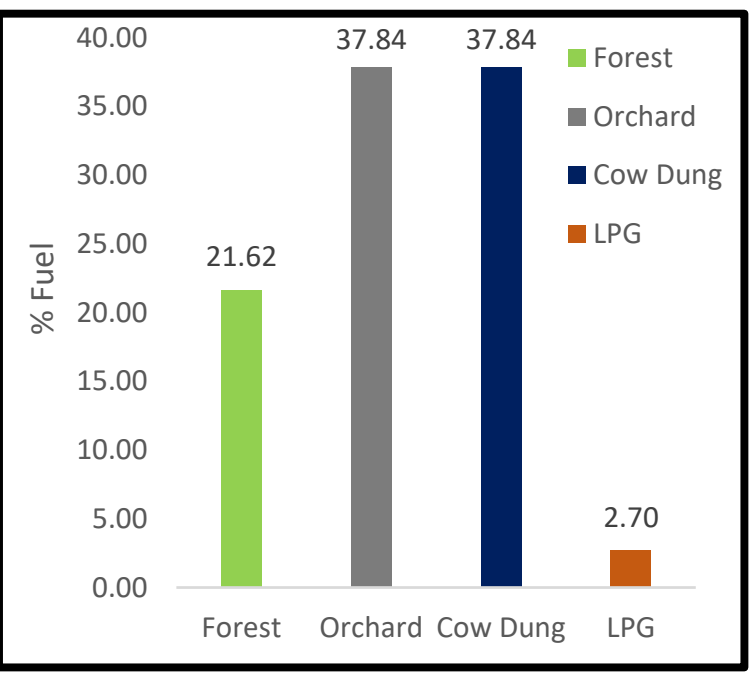

Figure 10: Percentage fuel items used by local community

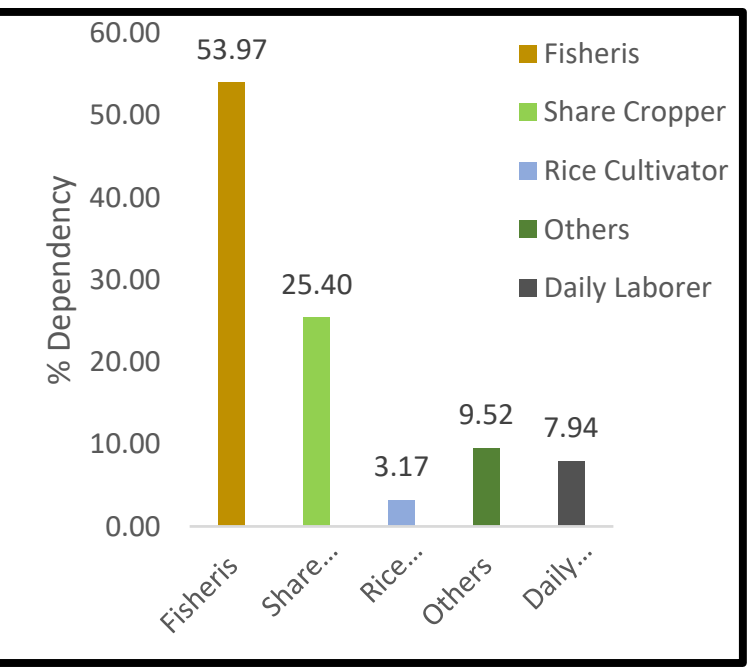

Figure 11: Percentage dependency of local community on different occupation 
Fuel use

The graph 12: shows $45.33 \%$ people are dependent on forest for firewood, $44 \%$ people are dependent on orchard wood, $2.66 \%$ people are dependent on cow dung, $6.66 \%$ people are dependent on LPG, and $1.33 \%$ people are dependent on Coal. This shows maximum number of people are dependent on Forest for firewood consumption followed by orchard wood, LPG, Cow dung and Coal.

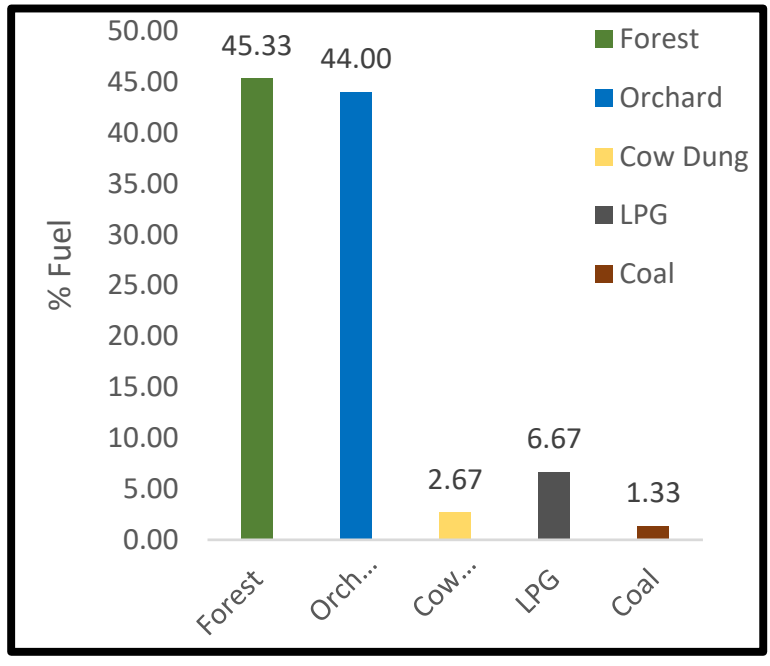

Figure 12: Percentage fuel items used by local community

\section{Analysis of total resource use pattern and livelihood of households}

The graph 13: is the representation of dependency of local people in total 6 villages of Batighara panchayat. Out of 6 villages 5 villages are highly dependent on Fisheries. The second most occupation is Share cropping in all villages excluding Batighara. In rest three villages (Barkolikhola, Kochila, Kajalpatia) there is alternative source of income. In all the villages excluding Batighara Share croppers are more than Rice cultivators and daily laborers are also more than rice cultivators due to lack of land ownership.

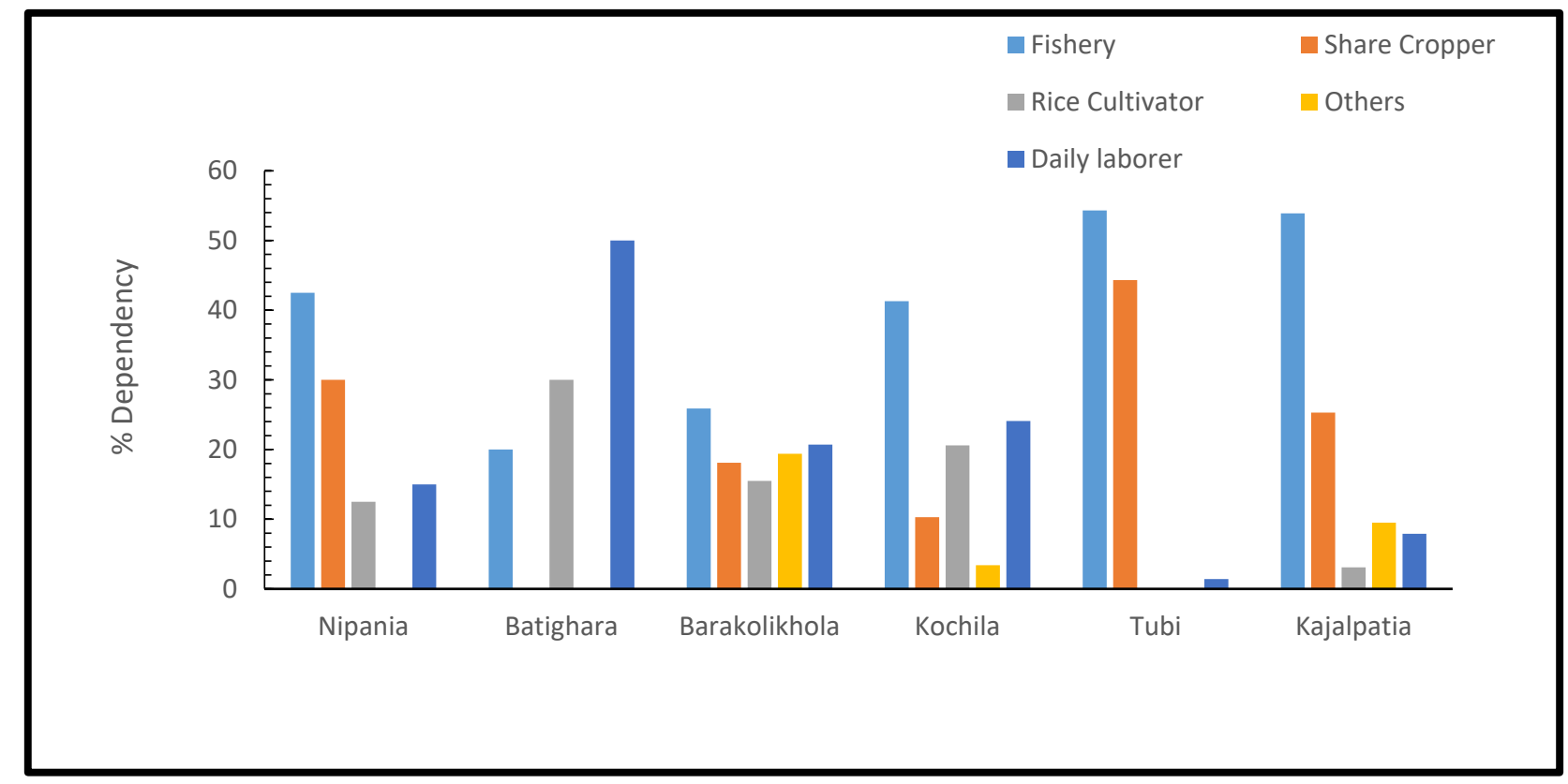

Figure 13: Percentage dependency of local communities on different occupation 
The graph 14: shows the fuel consumption in 6 villages of the study area. In 2 villages (Nipania, Kajalpatia) firewood collection from the forest is high. In 4 villages (Batighara, Barkolikhola, Kochila, Tubi) uses of cow dung is high followed by firewood from forest. The second most used energy is cow dung which is used by all the villages excluding Kajalpatia village. Coal is another source of fuel is only observed in 1 village Kajalpatia during surveying period. LPG is used by almost all the villages but in less amount but in the village Tubi it is preferred more than other villages. People from every village used to go forest twice or thrice in a month. Only one person is allowed from one family to go to the forest according to the village people. Female mostly goes for the wood collection and can collect firewood only once in a collection time. One female can carry $20-25 \mathrm{~kg}$ per head load.

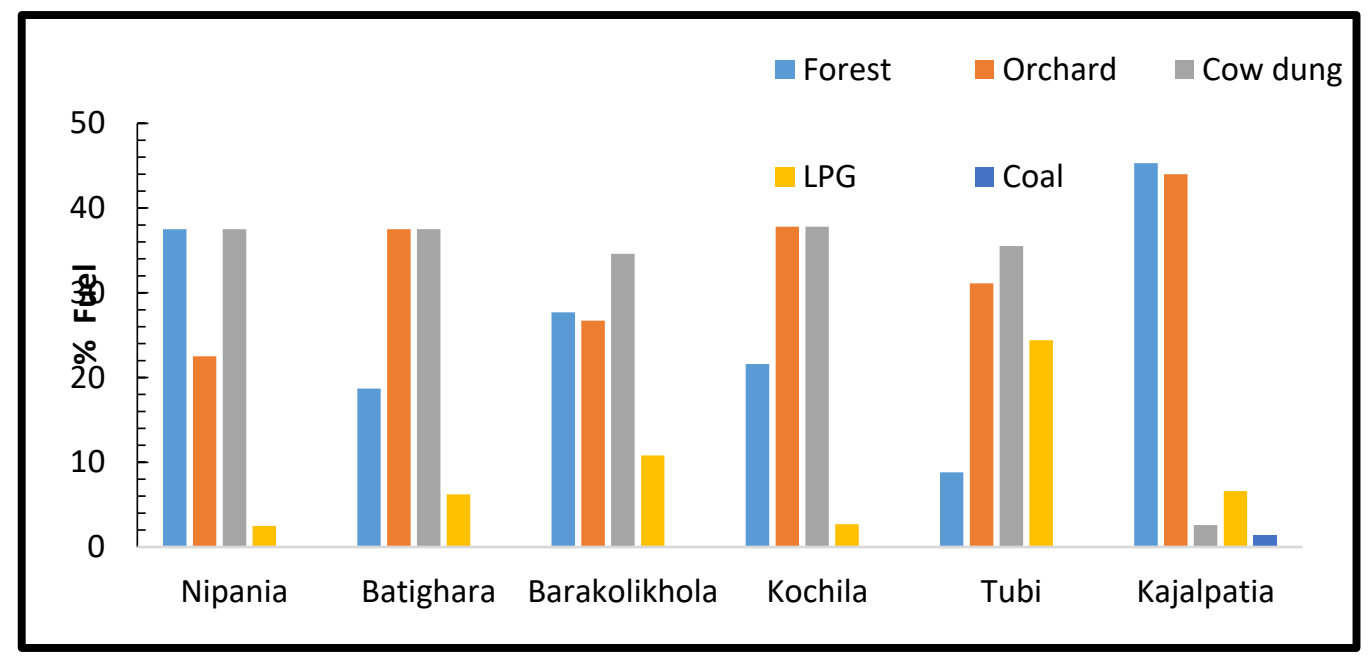

Figure 14: Percentage fuel items used by local communities

The graph 15: respresnts the responses of 170 respondents of overall villages which holds $57.1 \%$ for forest ,68.8\% for orchard,61.2\% for cow dung and $24.1 \%$ for LPG. This represents Orchard is highly used for fuel item collection followed by Cow dung, Forest and LPG.

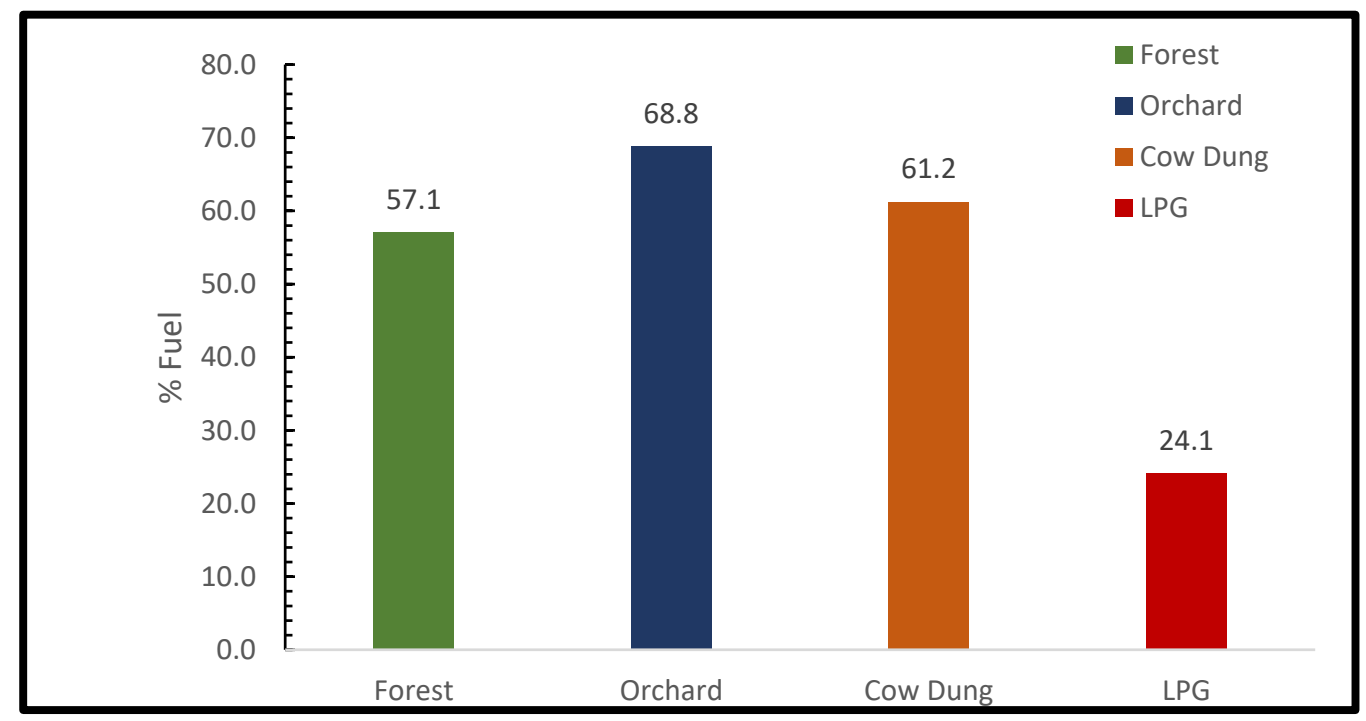

Fig15: Total fuel dendency by community 


\section{Human wildlife conflict}

During this survey $81.15 \%$ respondents of 6 villages asked for wild boar conflict and $18.84 \%$ people told about Crocodile conflict. According to the respondent's, wild boar are mainly seen in the month of Oct to Dec during winter because of paddy cultivation season. In the other months of the year also conflict happens. Other months Boar mainly prefer sweet potato and other vegetables from the orchard of local people.

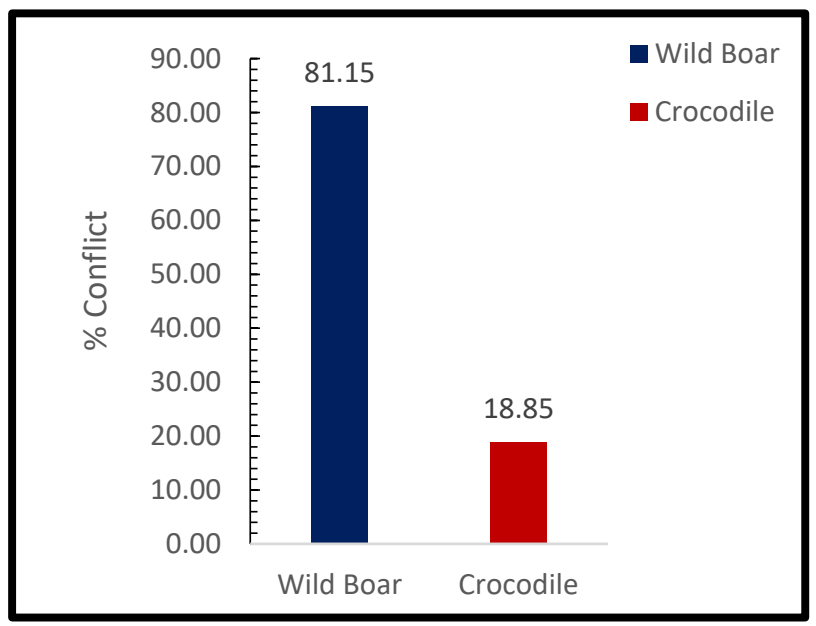

Figure 16: Human Wildlife Conflict

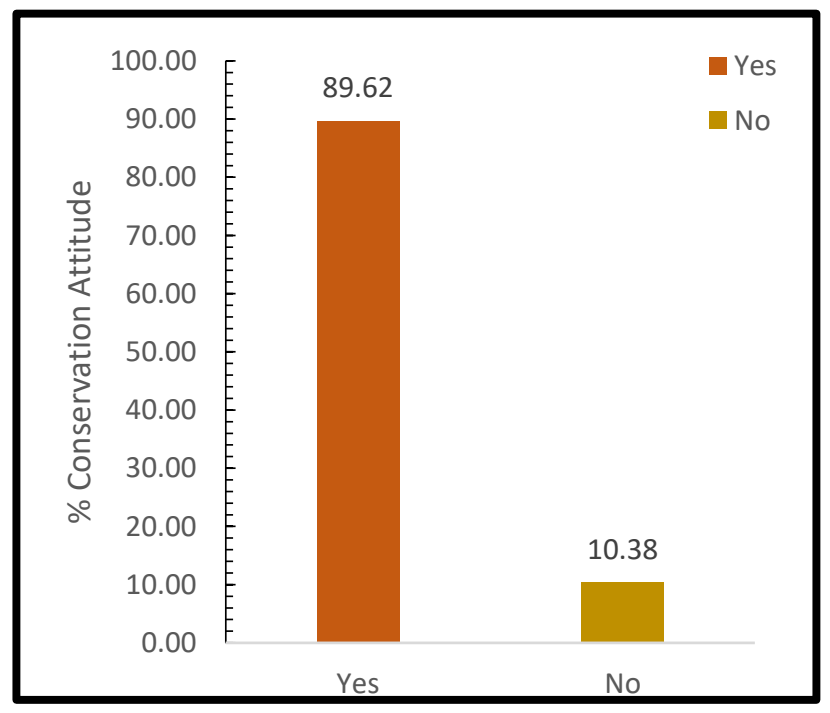

Figure 17: Percentage of Conservation Attitude

\section{Conclusion and Recommendations}

Mangrove are Tropical and costal vegetation found in costal river delta. They are highly adapted to these area. According to different studies it is stated that $100 \%$ people are dependent on forest for firewood consumption. According to the survey not all villages are fully dependent on forest for firewood collection. The villages in which people have large Orchard they collect wood mostly from there, and the villagers those who have their own cow and calf they are mostly dependent on cow dung for fuel and least dependent on forest for firewood collection. Similarly occupation of most villages like Nipania, Barkolikhola, Tubi, Kajalpatia and Kochila is fisheries. These people are economically very poor so they are highly dependent on fisheries. These people don't have their own crop land so next maximum income source is share cropping. Firstly Due to wild Boar conflict most of the people are refrain from doing cultivation over there. Secondly maximum people are daily wage laborer. Inside those villages there is no alternative source of income that's why many people used go outside like Paradwip town to work. They work as daily laborer and sharing cropper to meet their daily needs. Very few people have their own shops inside village. Third most problem which was noticed during study period is pollution. Pollution is the major threat to the mangrove ecosystem. Polluted water from industries present in Paradwip port highly influences mangrove growth. Effluents and polluted water from pesticide industry is easily released without treatment and gets mixed with river water which effects leaves of mangrove vegetation nearby and leads to their turning black. 
Last of all in that area some people from outside of village cut mangroves and make artificial ponds (Gheri) for fish culture, shrimp culture etc. That affects the mangrove population. Those people also clear forest for paddy cultivation. Due to strictness of forest department, some ponds are converted into mangrove forest but still some artificial ponds remains to be converted into mangrove forests. People are aware about the positive effect of forest according to the study high percentage of people showed positive attitude towards mangrove conservation. This shows attitude of local people towards conservation is positive so it will easier to conserve mangrove and we can involve local community in development and conservation in this area.

\section{Recommendations}

1. Emphasize should be given on the local stakeholder involvement in mangrove forest conservation.

2. Involvement of NGOs and forest department in the process of capacity building and mobilizing the public opinion and motivating local people towards forest protection.

3. Legal enforcement should be streamlined to solve the cases regarding forest encroachment and mitigating human wildlife conflict as soon as possible by providing them compensation timely.

4. From this study it is concluded that by providing alternative source of fuel may reduce the dependency of local people on mangrove forest. In this study villages Gobar gas plant should be promoted due to high density of cattle. Furthermore, whatever alternative have supplied should be accessible to villagers.

5. Support for alternative source of income can raise the socio economic status of people. This area is famous for its light house and Hukitola island fort so it should be promoted as eco-tourism areas to facilitate jobs for local people. Other than paddy mushroom cultivation, Honey production should be facilitate by Government.

6. Promoting SHGs to strengthen the women for conservation process.

7. More extensive future research in clarifying the variables influencing dependency of local communities on Mangrove forest in Mahanadi Delta is highly recommended.

Acknowledgment

This research would not have been possible without the tremendous help, support and patience of numerous people over the months, from supervisors to well-wisher. It is impossible to thank everyone who has helped me and this work along the way. To all involved directly and on the periphery, I offer my most sincere appreciation and thanks. Several individuals have made this study on community dependence on mangroves successful and I would like to express my sincere gratitude to everyone. My sincere appreciation and thanks are for Dr. NPS Chauhan, who served as my internal supervisor and who provided me with essential academic and scientific support, help and guidance throughout the work, enabling me to integrate science, conservation and academics. His valuable and friendly guidance on every stage of my research is greatly acknowledged. I express my sincere thanks to him during this phase. I sincerely thank Dr. Satyaranjan Behera, Zoologist of Odisha Biodiversity Board, for his constant help and support in carrying out this study successfully. My sincere thanks and appreciation are owed to all the Dr, Janmenjay Sethy for his help in data analysis and guidance at various stages of my field work. I truly and deeply wish to thank to my colleagues, co-author, Villagers of Batighara panchayat for support and cooperation in many ways.

\section{References}

Aksornkoae S (1986) Mangrove ecosystem general background. In: Training course on life history of selected species of flora and fauna in mangrove ecosystems pp 1723 UNDP/ UNESCO Regional Project (RAS/86/120)

Alongi DM (1994) The role of bacteria in nutrient recycling in tropical mangrove and other coastal benthic ecosystems. Hydrobiologia 285:19-32

Day J W, Conner W, Ley-Lou F, Day R H and Navarro A M (1987) The productivity and composition of mangrove forests, Laguna de Terminos, Mexico Aquatic Botany 27 267- 2844

Holguin G, Vazquez P, Bashan Y (2001) The role of sediment microorganisms in the productivity, conservation, and rehabilitation of the mangrove ecosystems: an overview. Biol Fertil Soils 33:265-278

Kathiresan K (2000) Mangrove atlas and status of species in India. Ministry of Environment and Forest, New Delhi, p 235

Kathiresan K and Bingham B L (2001) Biology of mangrove and mangrove ecosystems Adv Mar Biol 40 81-251

Kumar P (ed) (2010) The economics of ecosystems and biodiversity: ecological and economic foundations. Earthscan, London

Ong J E (1995) The ecology of mangrove conservation and management Hydrobiologia 295 343-351

Rojas A, Holguin G, Glick BR, Bashan Y (2001) Synergism between Phyllobacterium sp. (N2- fixer) and Bacillus licheniformis (P-solubilizer), both from a semiarid mangrove rhizosphere. FEMS Microbiol Ecol 35:181-187

Wildlife Conservation of Odisha, Forest and Environment Department, Goverment of Odisha, [Online] Available at: http://odishawildlife.org/mangroves.html. V.Selvam, K.K.Ravichandaran, V.M.Karunakaran, K.G.Mani, Evanjalin Jessie Beula and L.Gnanappazham (2010), Pichavaram mangrove wetlands: Situation Analysis, International Union for Conservation of Nature and Natural Resources. 


\section{AUTHORS}

First Author - Subhechha Tapaswini, MSc forestry and wildlife sciences, subhechhatapaswini@gmail.com .

Second Author - Sabmeet Singh, MSc Wildlife Sciences, University of Kota, sabmeetsingh@ gmail.com.

Correspondence Author - Dr. NPS Chauhan, Amity Institutes of Wildlife Science (AIWS) Amity University Campus, Sector-125,

Noida - 201303, Gautam Buddha Nagar U.P. (INDIA) Email:nschauhan@amity.edu 